\title{
COMMERCIAL CULTIVATION OF WATER CHESTNUT (TRAPA BISPINOSAROXB.) UNDER WETLAND ECOSYSTEM OF GOREGAONTALUKA IN GONDIADISTRICT, (M.S.) INDIA
}

\author{
Rane, V.I. and Suryawanshi, B.G \\ Jagat Arts, Commerce and IndirabenHariharbhai Patel Science College Goregaon, \\ Dist. Gondia. (M.S.) 441801 \\ Email- vijay_rane@,rediffmail.com, suryawanshi.bg@gmail.com
}

\begin{abstract}
:
The Gondia district is very famous as district of dams, ponds and pools in Maharashtra. This district has rich source of water bodies and serving for cultivation of Rice (Oryza sativa L.).The present study was conducted to find the impacts of Trapa bispinosa (water chestnut) in Goregaon taluka of Gondia district cultivating in the many ponds of rice fields. Total 07 numbers of rice field ponds are being used for the cultivation of water T. bispinosa (water chestnut) in study area. The ponds and wetlands possess rich and diverse biodiversity. T. bispinosa (water chestnut) is an excellent economical and medicinal winter crop from fresh water ecosystem grown in India. It is an aquatic nut crop grown mainly in the tropical and sub-tropical region, as submerged plant community. It thrives in the soft nutrient rich waters in the lakes, ponds and streams with neutral to slightly alkaline pH. The plant is well adapted to life at the water's edge and prospers even when standard along muddy shores. In India, it is most commonly used as edible nut. It has potentiality to increase the economic standard of the rural farmers.
\end{abstract}

Key words: - Trapa bispinosa, Goregaon taluka and sub-tropical region.

\section{INTRODUCTION:}

Goregaon is a taluka in Gondia District of Maharashtra State, India. It belongs to Vidarbha region and Nagpur Division. It is located $14 \mathrm{~km}$ towards south from District headquarters. Goregaon talukais a beautiful wetland located area at the elevation of $327 \mathrm{~m}$ above from sea level between latitude 21.348788 and longitude 80.212234 with an area of 484.42 sq.km.(Fig-1)The climate here is generally hot and dry whereas in the rainy season it is humid and the rainfall is quite heavy (appx.1400 mm). The temperature in summer goes above $45^{\circ} \mathrm{C}$ and in winter drops below $10^{\circ} \mathrm{C}$

Wetlands help inmaintaining the natural cycles and ecological diversity. It plays an important role in the economy of a region or country and has academic, societal and economic importance. They act as natural water reservoirs and store a large quantity of water, which can be used for irrigation, aesthetic and other purposes. Present study is focused to provide very first reporton the commercial impact of thewater chestnut(aaquatic weed) of the wetland in this region.

Fresh nut of Trapabispinosa (water chestnut) commonly called singhara, singhada or jalphal.It is well known for its high water content, starch, protein and Carbohydrates. Apart from these quality attributes, it is good source of fiber, Vitamin $\mathrm{B}$ along with $\mathrm{Ca}, \mathrm{K}, \mathrm{Fe}$ and $\mathrm{Zn}$. Water chestnuts are excellent source of crude fiber and it was for green variety $2.13 \%$ and red variety $2.27 \%$ (Faruket al., 2012). Adkaret al., (2014) reported nutritional and pharmacological aspects of Trapabispinosa. He 
fined protein and carbohydrate content of fresh water chestnut was $4.40 \%$ and $22.3 \%$, respectively. Water chestnuts are cholesterol and gluten free and have cooling and detoxifying effects. Even, water chestnuts are known to act as anti-ulcer, antibacterial, analgesic, diuretic and other human health problems (Mendhekarand Rachh, 2019). Besides, carbohydrates and protein it contained fair amount of flavonoid and antioxidant thus can be a potential source of nutrition (Mann et al., 2011). It is a knobby edible nut with a reddish black and pure green skin and a white crispy flesh (soft tissue). The people used the fruits as raw and boiled and consumed after separation of skin which have a sweet taste with a slight crunch. Boiled water chestnut removes free water and toxins which could cause for cough and cold.Despite varying levels of metals found in various fruit parts of $T$. bispinosa, the metal accumulation in kernel was alarming. However, metal content decreased significantly in various parts after boiling the fruit(Upendra N. RaiSarita Sinha, 2001). Cultivars used to boil the fruits by adding hirakashi (Ferrous Sulphate) and cut spines before selling to consumers.

Some beautiful wetlands may disturb their beauty by the tremendous growth of Trapanatans. Water chestnut hampers the charming beauty as well as the path of aquatic fauna. Sheetal Chaudhary and Dinesh Kumar, (2018) conducted study to find the impacts of $T$. bispinosaon Himalayan wetland of Deoriataluka from April, 2014- March, 2016 spreading in the epilimnetic zone of the wetland. The beautiful wetland is a tourist spot and is famous for its landscape and panoramic view of the nearby snowy mountain peaks that are reflected in the water, which are the main attraction for the tourists round the year.

Owners of all water ponds of 05 villages are not cultivating the water chestnut except two (Table-1\& Fig-3). These ponds are hand over to the other persons on contractual basis year wise for the cultivation of chestnut fruit. Especially peoples belonging to cast -kahar are engaged in this probation. Selling (marketing) of water chestnut properly carried out by the different peoples of locality as their business for daily earning sources. Irrigated rice field also used by some farmers for the cultivation of water chestnut as new alternative forming in this area of wetland (Fig-3 site No-4).

\section{Description of the plant}

TrapabispinosaRoxb. (Family: Trapaceae) is an annual, broadleaved and herbaceous freshwater macrophytic weed having slender roots that grows from the bottom with annual reproductive cycles. The persistent seeds usually germinate in the spring season. This macrophyte has a floating canopy of leaves with a submerged stem. The leaves petiole float on the surface of the water. The stems have many branched photosynthetic roots. The plant has single white and small flowers that grow in the center of the rosette. Each rosette can produce hard, nut-like and sharp spiny fruits in July(Fig-2). This plantgrows best in shallow and nutrient-rich water bodies with a $\mathrm{pH}$ range of 6.78.2 and calcium carbonate alkalinity of $12-128$ $\mathrm{mg} / 1$ (Charles, 2006).

When the fruit with older leaves is released from the parent plant, the central terminal meristem produces new leaves in the rosette (Grothet al., 1996). The plant spread in the shallow water bodies at a very fast rate, deteriorating the health of the aquatic ecosystem.

\section{Propagation}

Propagation of the plant is commercially done by seeds. The fully mature nuts are placed in container with little water to germinate the seeds. The sprouted seeds are stored out and broadcast in the nursery tanks. At the beginning of monsoon, the seedlings are lifted from the nursery tanks and planted in ponds, at a spacing of 1-2 meters or 2-3 meters when the soil of pond is fertile.

\section{Climatic requirement}

Water temperature of $12-15^{\circ} \mathrm{cis}$ absolutely necessary for the fruit to germinate while $20^{\circ} \mathrm{C}$ is required for development of the flower. The 
temperature range throuout the years are dependent on continental climatic condition that is high temperature during spring and summer and low in winter is beneficial for successful production of the crop.

\section{Soil and nutrients managements}

As it is an aquatic plant, soil does not play much important role for its cultivation. But it is found that water chestnut gives better yield when the soil of water bodies is rich, friable which is well fertilized. Water chest-nut requires some specific nutrients for better growth and development. Fertilizer with moderate's amount of poultry manure is very essential for higher yield. But it needs little application of phosphorus and potassium. 30-40 kg of urea in per ha area of pond after about a month of transplanting and again after another 20 days is highly recommended.

\section{Transplanting}

It is recommended that plants are first grown in a low nutrient nursery plot and transferred when stem are about $300 \mathrm{~mm}$ tall. This reduces the growth period in ponds by up to 6 weeks. Tops may be trimmed if they are too tall at transplanting. Care should be taken at the time of transplanting so that seedlings kept moist but cot submerged.

Water for chestnut crop The soil should be kept flooded with $100 \mathrm{~mm}$ to $300 \mathrm{~mm}$ of water throughout the growing period. A greater depth of water is tolerated by the plant. On large scale they are grown.

in flooded fields like rice. These fields are ideally located below a water sources like a dam sothat the water level can be maintained with a gravity flow. They can also be grown on dam and pond edges but only if the water level is controllable and stable.

\section{Intercultural operations}

Reduction of water in the pond due to draught may create difficulty and in such a case, it should be refill with water from other source. Luxuriant vegetative growth of the plant may results in highly fertile condition of the medium with lower productivity of the plant and hence mild pruning become necessary in such case. Regular eradication of aquatic weeds especially Hydrilla, Lemna, Azolla and Eicchornia is most important during the cropping season.

\section{Flowering and fruit development}

General it flowers during July and August.During the summer months the fruit develops at the basal portion of the rosette of leaves. In autumn the leaves change color from green to purple-brown, the rosette dissolve and the fruit started to sinkto the bottom of the lake or pond water and anchor with their thorns in the silt sediment. The cycle starts again in the following spring. Large birds beavers others transport the fruits from one habitat to other. It is also speculated that prehistoric people dispersed the nuts intentionally.

\section{Harvesting and yield}

Harvesting of nut is usually done at the month of September and continues up to November. For the purpose of harvesting, specially made rafts(small wooden boats) are used by the growers. 2500-3500 $\mathrm{kg}$ per ha could be increased up to $5000 \mathrm{~kg}$ per ha by applying about $50 \mathrm{~kg}$ of urea per ha of pond along with eradication of weeds.

\section{Storage}

Harvested kernels can be stored in the bottomof the fridge in sealed plastic bags or containers to prevent them from drying out. There are always a few that rot during storage and need to be sorted out from time to time. This rot is often due to even slight damage to the skin during harvesting \& later handling. They keep quit well in the ground where they grew while the temperature stays low enough to maintain dormancy. Dried out kernel or ones that have been frozen will not grow. They also keep very well in cool damp sand. We can keep kernel under this condition for over a year for seed purpose.

\section{CONCLUSION}

T. bispinosa is nativeaquatic weed is using as edible fruit yielding plant in studied area. Water chestnut fruits have good food value with starch, protein and 
Carbohydrates.Formers of this taluka can took good opportunity as alternative forming of water chestnut in their irrigated rice field, if they have required availability of water resources. The traditional knowledge about the cultivation of this crop can be utilized from the persons who are belonging in cast- Kahar specially. The agriculture department and the local agencies should come up with the best solution measures for its conservation and management of cropping. Different level of peoples like owners of water bodies, formers (who actually cultivating the nut) and sellers of nut in market getting the commercial benefit from this forming of wetland. As this plant has some medicinal properties too, the awareness movement should be organized for the local people to make them aware of the use as well as effects. Fish forming is also possible in these kind of wetlands.

\section{REFERENCES:-}

Adkar, P., Dongare, A., Ambavade, S. and Bhaskar, V.H. (2014): TrapabispinosaRoxb.: A Review onNutritional and Pharmacological Aspects. Advances in Pharmacological Sciences, pp13.DOI:http://dx.doi.org/10.1155/2014/95 $\underline{9830}$.

Charles R. O’Neill, Jr. (2006): Water Chestnut (Trapanatans) in the Northeast NYSG Invasive SpeciesFactsheet Series, 06-1, pp.1-4.

Groth, A. T., Lovett-Doust, L., and Lovett-Doust, J. (1996): Population density and module demography inTrapa natans

(Trapaceae), an annual, clonal aquatic macrophyte. American Journal of Botany, 83: $1406-1415$.

Faruk, M.O. , Amin, M.Z., Sana N.K., Saha, R.K. and Biswas, R.K. (2012).Biochemical analysis of two varieties of water chestnuts (Trapaspp). Pakisthan Journal of Biological Sciences, 15(21):1019-1026.

Mann, S., Gupta, D. Gupta, V. and Gupta, R.( 2011). Evaluation of nutritional, phytochemical, and antioxidant potential of TrapabispinosaRoxb. fruit. Retrieved November 17, 2017, from http://www.ijppsjournal.com/Vol-4Issue1/3050.pdf

Upendra N. RaiSarita Sinha (2001)Distribution of Metals in Aquatic Edible Plants: TrapaNatans (Roxb.) Makino and Ipomoea AquaticaForsk, Environmental Monitoring and Assessment,Volume 70(3)241-252

Sheetal Chaudhary1 and Dinesh Kumar2.(2018),TrapanatansL. (Water Chestnut) In Himalayan Wetland Deoria Tal, India, Int. J. Adv. Res. 6(8), 583-587

MendhekarSeemaYuvraj and Dr. Punit R. Rachh(2019).Review: Pharmacognostic, Phytochemical \& Pharmacological Evaluation of TrapanatansLinn.,Jou. ofPharma Research Vol. 8,(4), 219-223 


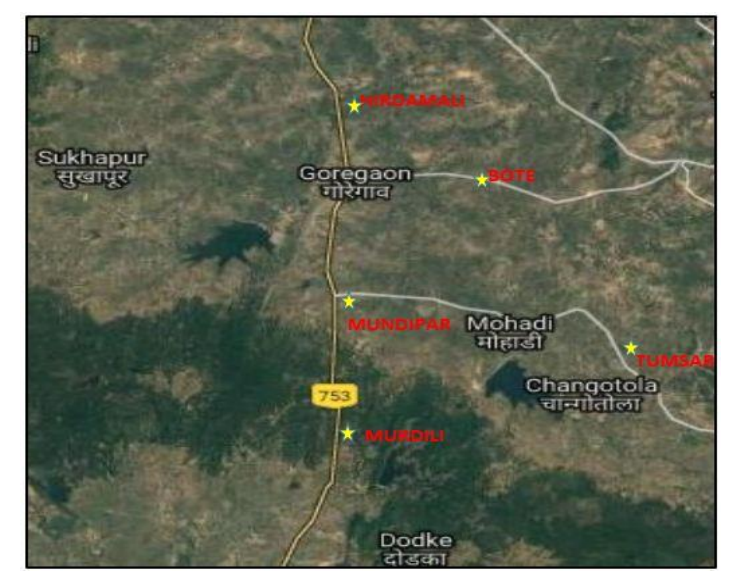

Fig: -Map of GoregaonTaluka showing the Location of Cultivation

Table:-1 Owners and Cultivators of Chestnut at different Villages of GoregaonTaluka

\begin{tabular}{|l|l|l|l|l|l|}
\hline $\begin{array}{l}\text { Sr.N } \\
\text { o. }\end{array}$ & $\begin{array}{l}\text { Name of the owner } \\
\text { of water body }\end{array}$ & Village & $\begin{array}{l}\text { Name of the } \\
\text { cultivator }\end{array}$ & $\begin{array}{l}\text { Area of water } \\
\text { body }\end{array}$ & $\begin{array}{l}\text { Appx. } \\
\text { per year (Rs.) }\end{array}$ \\
\hline 1 & HemantPatle & Hirdamali & FularamDudhbarai & 1.5 Acre & $1,30,000 /-$ \\
\hline 2 & ManojKatre & Bote & PandurangBarve & 1.5 Acre & $1,10,000 /-$ \\
\hline 3 & ThaganbaiShende & Mundipar & NandajiMeshram & 2.4 Acre & $1,85,000 /-$ \\
\hline 4 & KeshoraoBagde & Tumsar & KeshoraoBagde & 0.25 Acre & $25,000 /-$ \\
\hline 5 & Vithoba Chute & Tumsar & MangalDudhbarai & 0.25 Acre & $25,000 /-$ \\
\hline 6 & RajaramAlagdeve & Tumsar & RajaramjiAlagdeve & 0.25 Acre & $30,000 /-$ \\
\hline 7 & HiwrajTekam & Murdoli & DhanlalDudhbarai & 2.0 Acres & $1,45,000 /-$ \\
\hline
\end{tabular}

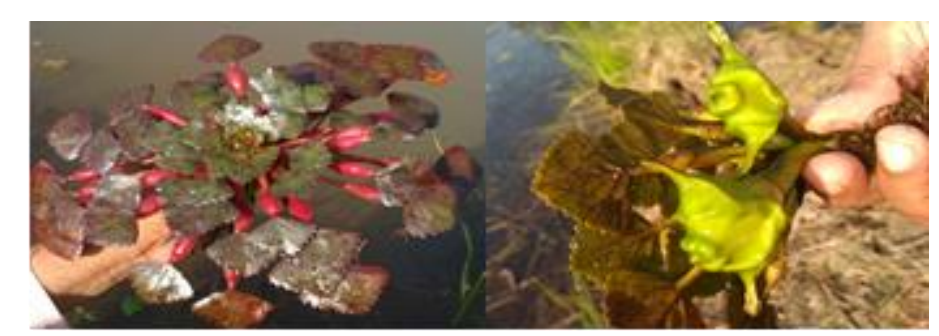

Fig: -2. Morphology of plant \& fruits 
I J R B A T, Issue (VIII), Vol. I, Jan 2020: 139-144

A Double Blind Peer Reviewed Journal
OPEN $\bigcirc$ ACCES

e-ISSN 2347 - 517X

Original Article
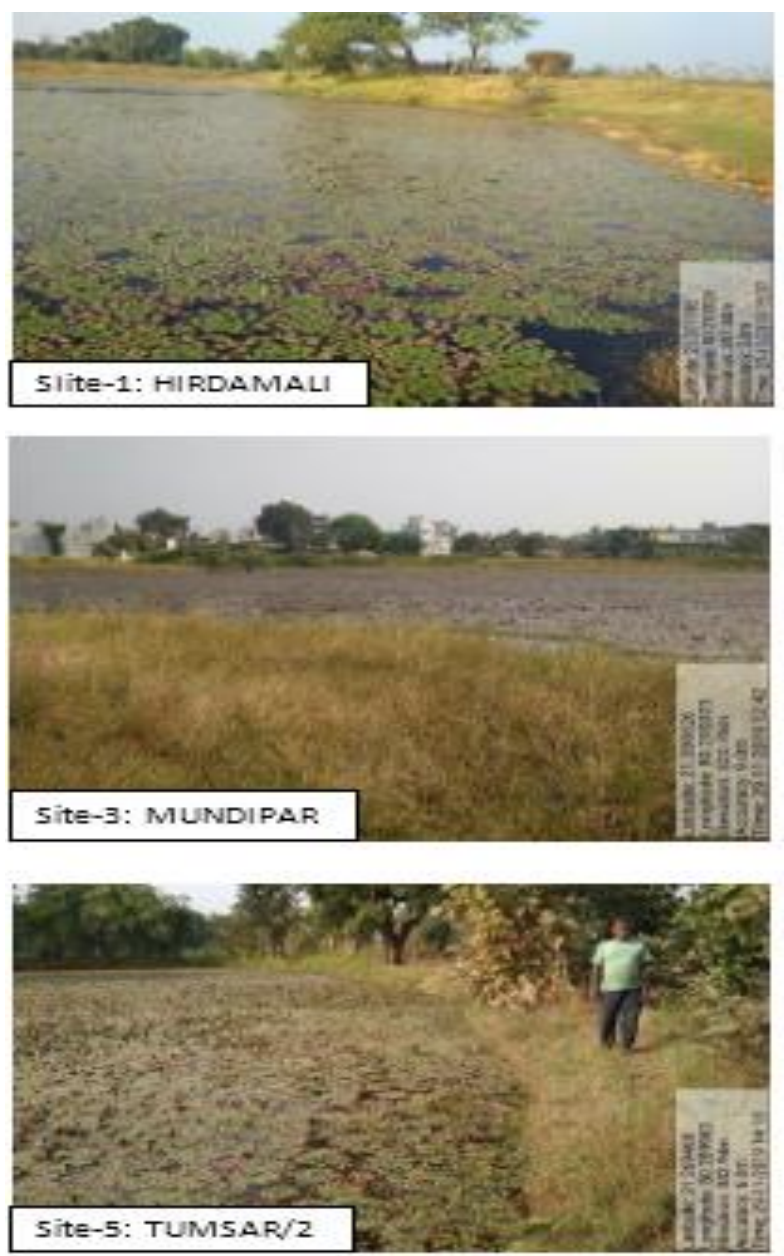
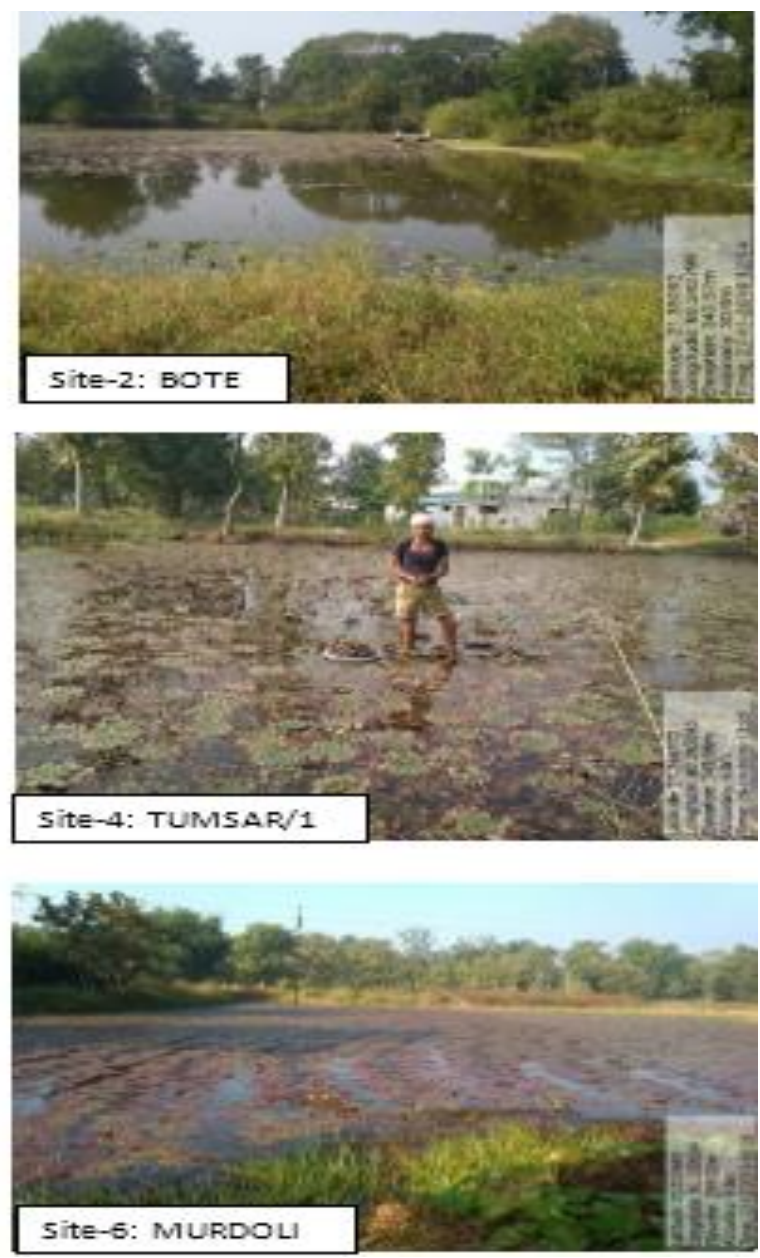

Fig: -3 Different sites where Trapa bispinosa Roxb. Cultivated 